\title{
1 Small-scale response of plant species to land-use intensification
}

2

3 Éric Fédoroff ${ }^{\mathrm{a}}$, Jean-François Ponge ${ }^{\mathrm{b} *}$, Florence Dubs ${ }^{\mathrm{c}}$, Federico Fernández-González ${ }^{\mathrm{d}}$, Patrick

$4 \quad$ Lavelle $^{\mathrm{c}}$

5

6

${ }^{a}$ Museum National d'Histoire Naturelle, Conservatoire Botanique National du Bassin Parisien, Maison du Parc, 58230 Saint-Brisson, France

${ }^{b}$ Museum National d'Histoire Naturelle, CNRS UMR 5176, 4 avenue du Petit-Chateau, 91800 Brunoy,

France

'Institut de Recherche pour le Développement, UMR 137 BioSol, 32 rue Henri Varagnat, 93143 Bondy

Cédex, France

12

¿Universidad de Castilla-La Mancha, Facultad de Ciencias del Medio Ambiente, Departamento de Ciencias Ambientales, 45071 Toledo, Spain

Abstract

Plant communities are affected by land-use and landscape heterogeneity and can be used as indicators of environmental change. At small-scale, species composition and species richness of plant communities are influenced by local environment and by diaspores from the surroundings. Thus they reflect the influence of both land-use type and land-use diversity. Plant community composition was studied along a gradient of agricultural disturbance in the Morvan Regional Natural Park (Burgundy, France). Six landscape units of $1 \mathrm{~km}^{2}$ were selected along a range of increasing land-use intensity. Sixteen $0.2 \mathrm{~m}^{2}$ sampling plots per unit were selected according to a grid-based design to estimate the percent cover of all plant species. Pattern analysis showed that local species richness increased from woodland to crop to grassland, and also increased with land-use diversity. Local plant biodiversity was maximized under intermediate disturbance intensity and minimized at low (woodland) and high (crop) disturbance levels.

27

\footnotetext{
*Tel.: +33-1-60479213; Fax +33-1-60465009.

E-mail address: jean-francois.ponge@wanadoo.fr
} 


\section{Introduction}

Plant species are good indicators of soil conditions (Dahl et al., 1967; Ellenberg et al., 1992; Lee, 1999). Natural or man-induced disturbance in soil conditions is reflected in the species composition and richness of most plant communities (Falkengren-Grerup, 1986; Pettit et al., 1995; Roem and Berendse, 2000). Some plant species are also able to modify their environment between establishment and maturity (Miles, 1985; Muys et al., 1992; Bernier, 1996) and interfere with other species through competition, biochemical control and facilitation (Facelli and Facelli, 1993; Wardle et al., 1998; Chou, 1999). Land-use history may influence soil and vegetation long after conditions for the original establishment of plant species have disappeared (Koerner et al., 1997) due to feed-back processes (Ponge, 2003), and persistence of plant organs and diaspores (Zobel and Antos, 1986; Thompson et al., 1994).

14 1993; Nilsson et al., 1999). according to the following scale:

1. old-growth forest

2. managed forest

The present paper aims to discern whether local plant biodiversity expressed in terms of species richness is influenced by land-use intensification and/or landscape diversity, and whether above- and below-ground diversity follow the same trend along a gradient of land-use intensification. Land-use intensification was defined subjectively by the increasing impact of man on the landscape

3. mixed landscape dominated by woodland

4. mixed landscape not dominated by a single land-use

5. mixed landscape dominated by pasture

6. mixed landscape dominated by arable crops

The choice of local plant biodiversity over regional biodiversity (Tilman, 1999; Poiani et al., 2000; Loreau et al., 2001) was due to the need to account for site factors but also for interference and facilitation processes between plant individuals and species (Hester et al., 1991a; Facelli and Facelli, 


\section{Material and methods}

2 climate with continental influence, a mean annual rainfall of $1000 \mathrm{~mm}$, an temperature of $9^{\circ} \mathrm{C}$. The parent rock is granite, with moderate to strong soil acidity, and dominant humus form as mull (Perrier, 1997; Ponge et al., 2003). Forested areas (45\% in the region) comprise coniferous plantations [45\%, i.e. silver fir, Abies alba Mill., white fir, Abies grandis (Dougl. Ex D. Don) Lindl., Douglas fir, Pseudotsuga menziesii (Mirb.) Franco, spruce, Picea abies (L.) Karst.], and deciduous stands (55\%, i.e. common beech, Fagus sylvatica L. and sessile oak, Quercus petraea (Mattusschka) Lieblein). Agricultural areas (55\% in the region) consist of grassland $(80 \%$, half of which are permanent pastures and the other half temporary hay meadows) and mostly cereal crops $(20 \%$, i.e. wheat, Triticum aestivum L., barley, Hordeum vulgare L., rye, Secale cereale L. and Christmas trees). knowledge and aerial photographs:

22

- Unit 1 in a 100-150 year deciduous forest landscape managed by the public sector, with natural regeneration and selection by man.

Agricultural systems vary from extensive to organic farming whereas rural depopulation and forestry policies influenced the landscape over the last five decades (Plaisance, 1986). Many forests have been transformed into coniferous plantations and more recently agricultural land was afforested using national subsidies. In parallel, agriculture shifted from a short (food crop/fallow) to a long rotation system (grassland/cereal crop).

Six representative $1 \mathrm{~km}^{2}$ landscape units were intuitively selected on the basis of regional 2 4

- Unit 2 in a 50 year coniferous (mainly silver fir) forest landscape managed by the public sector, with artificial regeneration (clear-cut followed by plantation). Unit 2 used to be a deciduous forest similar to Unit 1. 
- Unit 3 in a landscape privately afforested 50 years ago with Douglas fir, spruce, and meadows. Remains of the old deciduous forest and some cereal crops were also present.

- Unit 4 in a mosaic of wet meadows, with some 30 years old Douglas fir and spruce.

- Unit 5 in a meadow landscape dominated by organic farming, with a rotation between meadow (6-10 years) and crop (2-4 years), with a few 20-50 year Douglas fir or spruce plantations.

- Unit 6 in an agricultural landscape dominated by conventional cereal crops with some fallow

Using aerial photographs a grid of 16 regularly spaced points (200 m mesh size) was projected on each of the six units, and retrieved using a calibrated GPS system. Each sample point was indicated by a central post used as a reference by all teams participating to the research program which involved springtails, lichens, butterflies, birds, soil macroinvertebrates, carabids, and remote sensing. The random selection of sample points was not the best method to detect vegetation patterns (Gillison and Brewer, 1985), but allowed all scientists to use the same sampling design, and comparisons between countries and taxonomic groups to be made. Vegetation was studied from July to November 2001 across a range of six nested areas $\left(50,25,12.5,5,1\right.$ and $\left.0.2 \mathrm{~m}^{2}\right)$, at fixed distance and orientation from the central post. Small-scale study of vegetation was conducted on $0.5 \times 0.4 \mathrm{~m}$ $\left(0.2 \mathrm{~m}^{2}\right)$ areas. These areas were located $10 \mathrm{~m}$ East from the central post. Percentage cover by the various plant species, vegetation categories (moss, lichen, herb, shrub, tree, total), stone, and litter was estimated visually to the nearest $5 \%$.

The Humus Index was measured at each sampling plot according to Ponge et al. (2002) and Ponge et al. (2003). Waterlogging in the top $10 \mathrm{~cm}$ was recorded and landscape heterogeneity measured by the diversity of land-use within each unit, using Shannon (1948) formula. communities (Greenacre, 1984). The principal variables were species cover, and plant categories. 
1 Additional variables were litter and stone cover, local biodiversity, units and land-use types (Table 1),

2 humus forms, Humus Index, and waterlogging. Discrete variables were coded as 1 or 0 . To give the

3 same weight to all parameters all variables were transformed into $X=(x-m) / s+20, x$ being the original

4 value, $m$ the mean of a given variable, $s$ its standard deviation. The addition of a constant factor of 20

5 allowed all values to be positive. Following transformation, factorial coordinates of variables were

6 interpreted directly in terms of their contribution to the factorial axes. Variables were doubled to allow

7 for the dual nature of measurement (Greenacre, 1984).

8

\section{3. Results}

10

Mixed or herbaceous dominated landscapes (units 3 to 6 ) had more plant species at the local scale than forested landscapes (Table 1). The curve for local plant biodiversity followed that of landuse diversity, and increased from unit 1 to unit 4 then decreased from unit 4 to unit 6 (Fig. 1). The Spearman rank correlation coefficient between local plant biodiversity and land-use variety was significant at the 0.01 level $\left(r_{s}=0.89\right.$, d.f. $\left.=4\right)$.

(1)

Strong differences were observed between land-uses when pooling samples (Table 1). At the local scale grassland had more plant species than arable crops, fallows being intermediate, fallows and crops having more plant species than forests. These differences were of the same order of magnitude as those observed across landscape units, but standard errors of the means were smaller. The difference between agricultural land and woodland, with a high and a low number of plant species respectively, was reduced when comparing units (Fig. 2). Species richness increased by a factor of 3 in woodland from unit 2 to 4 , and decreased by a factor of 2 in agricultural land from unit 3 to 6 . Species richness showed a marked decrease in arable crops along the gradient of land-use intensification, and was positively influenced by landscape heterogeneity in both woodland and agricultural land.

In the CA of plant communities ${ }^{1}$, axis 1 was neglected because it separated only one sample with hydrophilic vegetation from all other samples. The projection of samples in the plane formed by

\footnotetext{
${ }^{1}$ Species list available upon request from the corresponding author
} 
axes 2 and 3 showed three branches, i.e. woodland, grassland and arable crops, fallows being positioned according to previous land-use for the most recent or as successional stages towards woodland.

The different units were positioned in the plane of axes 2 and 3 according to the dominance of land-use types within each of them (Fig. 3). Axis 2 showed that hay meadows and pastures clearly differed from crops by a denser and richer herb vegetation. Axis 3 depicted a gradient of increasing species richness and herb cover, decreasing litter and tree cover, and decreasing Humus Index according to land-use intensification. The significance of axis 3 associated the gradient of land-use intensification from unit 1 to 6 with increasing soil biological activity, as inversely measured by the Humus Index (Ponge et al., 2002), and increasing local plant biodiversity, as expressed by species richness per $0.2 \mathrm{~m}^{2}$. Axis 3 was significantly correlated with Humus Index $\left(r_{s}=-0.61, P<10^{-4}\right)$ and local plant biodiversity $\left(\mathrm{r}_{\mathrm{s}}=0.57, \mathrm{P}<10^{-4}\right)$.

\section{Discussion}

Grassland exhibited a higher level of plant biodiversity than arable crops (Fig. 2), an effect that can be explained by grazing or repeated mowing which increased nutrient cycling, created gaps, giving more chance to poorly competitive species to reach the canopy, and increased dispersion by animals or wind (Watt, 1960; Grime et al., 1987; Silverstone and Smith, 1988). Heavy grazing may, however, exert a detrimental influence on species richness (Pettit et al., 1995), whereas conventional farming may contribute to decrease plant biodiversity (Edwards, 1965). The decreasing local plant biodiversity observed in arable crops from unit 4 to 6 (Fig. 2) can be explained by a decrease in the number of landscape components, and by the absence of rotation between meadows and crops in unit 6. On the other hand, germination of dormant seeds after cultivation (Brenchley and Warington, 1930) can contribute to increase plant biodiversity when crops replaced meadows.

The land-use type did not explain all the variability observed in local plant biodiversity, since for a given land-use more heterogeneous landscapes exhibited more plant species per unit surface (Fig. 2). Strong differences in plant species composition occurred in the three habitats woodland, 
1 grassland and arable crops. Given the ability of most plant species to disperse, especially through birds and wind, the seed rain may be more diverse provided woodland, grassland and arable crops exchange diaspores at the scale of a unit. Dispersal ability (Hester et al., 1991b) and permeability of the landscape (Honnay et al., 2002) are important components of local plant biodiversity. In the Morvan region spatial heterogeneity reflects also temporal heterogeneity, through rotation between arable crops and meadows, which increased the effect of immediate dispersal (Rescia et al., 1995). In unit 4 , mostly represented by small thickets and woodland contiguous to agricultural land, local plant biodiversity was high and accounted for strong landscape heterogeneity (Collinge, 1996).

Landscape diversity may have contrasting effects on soil-dwelling animal communities (Ponge et al. 2003). Above- and belowground biodiversity may reinforce each other through positive feedbacks (Perry et al., 1989; Hooper et al., 2000; Ponge, 2003). The observed decrease in springtail species richness when landscape variety increases may be related in Morvan to more rapid changes in land-use in heterogeneous than in homogeneous landscapes (Ponge et al., 2003). Plants being much more rapidly dispersed than springtails (Collembola), at least at the scale of the study unit (Hester et al., 1991b), factors which can explain changes in local biodiversity of these two taxonomic groups are not necessarily similar. However, the high nutrient status of the ecosystem could enhance biodiversity of all categories of organisms (Ponge, 2003), as was observed in unit 6 . Soil fertility has been made responsive for losses of biodiversity of plants by by favouring fast-growing species (Huston, 1979; Tilman, 1982; Loreau, 1998), whereas Brandt and Rhoades (1972), Miller et al. (1977), Roem and Berendse (2000) demonstrated the contrary. We suggest that more attention should be paid to the plant toxicity of $\mathrm{N}$ compounds (Knight et al., 1992; Thomas et al., 1999) before claiming that nutrients are responsible for collapses in biodiversity through active competition.

Land-use type and diversity had some major effects on local plant biodiversity in the present study, although trends only were detected by CA (Benzécri, 1969; Loreau, 1998). Land-use intensification increased plant species richness by providing herbs with more light and nutrients. The highest level of disturbance (arable crops) decreased biodiversity against perennial plants and favoured annuals tolerant to agricultural practices. Compared to homogeneous ones, heterogeneous landscapes tend to include more species in the seed rain and create edge effects (Harris, 1988). As a 
result, the intermediate disturbance level, (hay meadows and pastures) exhibited the highest level of local biodiversity, particularly in units with high land-use diversity.

The Intermediate Disturbance Hypothesis (Connell, 1978) probably applies to vegetation (Molino and Sabatier, 2001), and to taxonomic groups with colonization rate exceeding the disturbance rate (Sheil and Burslem, 2003). The reverse is true for soil microarthropods, which benefit from a more stable environment but are vulnerable to changes in land-use (Ponge et al., 2003).

\section{Acknowledgements}

10

This study was part of the European Community program BioAssess EVK2-CT-1999-00041, coordinated by A. Watt (UK), who is greatly acknowledged for financial support and fruitful exchange of ideas between partners. Y. Capon and F. Choquet are also acknowledged for their skillful contribution to plant sampling. Language and clearity have been improved by anonymous referees, who are greatly acknowledged.

\section{References}

Benzécri, J.P., 1969. Statistical analysis as a tool to make patterns emerge from data. In: Watanabe, S. (Ed.), Methodologies of Pattern Recognition. Academic Press, New York, New York, pp. 35-74.

Bernier, N., 1996. Altitudinal changes in humus form dynamics in a spruce forest at the montane level. Plant Soil 178, 1-28.

Brandt, C.J., Rhoades, R.W., 1972. Effects of limestone dust accumulation on composition of a forest community. Environ. Pollut. 3, 217-225.

Brenchley, W.E., Warington, K., 1930. The weed population of arable soil. I. Numerical estimation of viable seeds and observations on their natural dormancy. J. Ecol. 18, 235-272.

Chou, C.H., 1999. Roles of allelopathy in plant biodiversity and sustainable agriculture. Crit. Rev. Plant Sci. $18,609-636$. 
Collinge, S.K., 1996. Ecological consequences of habitat fragmentation: implications for landscape architecture and planning. Landsc. Urb. Plan. 36, 59-77.

Connell, J.H., 1978. Diversity in tropical rain forests and coral reefs. Science 199, 1302-1310.

Dahl, E., Gjems, O., Kielland-Lund, J.Jr., 1967. On the vegetation types of Norwegian conifer forests in relation to the chemical properties of the humus layer. Medd. Norsk. Skogforsøgsv. 85, 503531.

Edwards, C.A., 1965. Effects of pesticides on soil invertebrates and plants. In: Goodman, G.T., Edwards, R.W., Lambert, J.M. (Eds.), Ecology and the Industrial Society. Blackwell, Oxford, UK, pp. 239-261.

Ellenberg, H., Weber, H.E., Düll, R., Wirth, V., Werner, W., Paulißen, D., 1992. Zeigerwerte von Pflanzen in Mitteleuropa. Erich Goltze, Göttingen, Germany.

Facelli, J.M., Facelli, E., 1993. Interactions after death: plant litter controls priority effects in a successional plant community. Oecologia 95, 277-282.

Falkengren-Grerup, U., 1986. Soil acidification and vegetation changes in deciduous forest in southern Sweden. Oecologia 70, 339-347.

Gillison, A.N., Brewer, K.R.W., 1985. The use of gradient directed transects of gradsects in natural resource surveys. J. Environ. Manag. 20, 103-127.

Greenacre, M.J., 1984. Theory and Applications of Correspondence Analysis. Academic Press, London, UK.

Grime, J.P., Mackey, J.M.L., Hillier, S.H., Read, D.J., 1987. Floristic diversity in a model system using experimental microcosms. Nature 328, 420-422.

Harris, L.D., 1988. Edge effects and conservation of biotic diversity. Conserv. Biol. 2, 330-332.

Hester, A.J., Gimingham, C.H., Miles, J., 1991b. Succession from heather moorland to birch woodland. III. Seed availability, germination and early growth. J. Ecol. 79, 329-344.

Hester, A.J., Miles, J., Gimingham, C.H., 1991a. Succession from heather moorland to birch woodland. II. Growth and competition between Vaccinium myrtillus, Deschampsia flexuosa and Agrostis capillaris. J. Ecol. 79, 317-328.

Honnay, O., Verheyen, K., Hermy, M., 2002. Permeability of ancient forest edges for weedy plant species invasion. For. Ecol. Manag. 161, 109-122. 
1 Hooper, D.U., Bignell, D.E., Brown, V.K., Brussaard, L., Dangerfield, J.M., Wall, D.H., Wardle, D.A., Coleman, D.C., Giller, K.E., Lavelle, P., Van der Putten, W.H., De Ruiter, P.C., Rusek, J., Silver, W.L., Tiedje, J.M., Wolters, V., 2000. Interactions Between Aboveground and Belowground Biodiversity in Terrestrial Ecosystems: Patterns, Mechanisms, and Feedbacks. BioScience 50, 1049-1061.

Huston, M., 1979. A general hypothesis of species diversity. Am. Nat. 113, 81-101.

Knight, D., Elliott, P.W., Anderson, J.M., Scholefield, D., 1992. The role of earthworms in managed permanent pastures in Devon, England. Soil Biol. Biochem. 24, 1511-1517.

Koerner, W., Dupouey, J.L., Dambrine, E., Benoît, M., 1997. Influence of past land-use on the vegetation and soils of present day forest in the Vosges mountains, France. J. Ecol. 85, 351358.

Lee, J.A., 1999. The calcicole-calcifuge problem revisited. Adv. Bot. Res. 29, 1-30.

Loreau, M., 1998. Biodiversity and ecosystem functioning: a mechanistic model. Proc. Nat. Acad. Sci. 95, 5632-5636.

Loreau, M., Naeem, S., Inchausti, P., Bengtsson, J., Grime, J.P., Hector, A., Hooper, D.U., Huston, M.A., Raffaelli, D., Schmid, B., Tilman, D., Wardle, D.A., 2001. Biodiversity and ecosystem functioning: current knowledge and future challenges. Science 294, 804-808.

Miles, J., 1985. The pedogenic effects of different species and vegetation types and the implications of succession. J. Soil Sci. 36, 571-584.

Miller, H.G., Williams, B.L., Millar, C.S., Warin, T.R., 1977. Ground vegetation and humus nitrogen levels as indicators of nitrogen status in an established sand-dune forest. Forestry 50, 93-101.

Molino, J.F., Sabatier, D., 2001. Tree diversity in tropical rain forests: a validation of the intermediate disturbance hypothesis. Science 294, 1702-1704.

Muys, B., Lust, N., Granval, P., 1992. Effects of grassland afforestation with different tree species on earthworm communities, litter decomposition and nutrient status. Soil Biol. Biochem. 24, 14591466.

Nilsson, M.C., Wardle, D.A., Dahlberg, A., 1999. Effects of plant litter species composition and diversity on the boreal forest plant-soil system. Oikos 86, 16-26. 
1 Perrier, P., 1997. La forêt au Mont Beuvray: phytoscociologie. In: Buchsenschutz O., Richard, H. (Eds.), L'Environnement du Mont Beuvray. Éditions du Centre Archéologique Européen, Gluxen-Glenne, France, pp. 71-84.

Perry, D.A., Amaranthus, M.P., Borchers, J.G., Borchers, S.L., Brainerd, R.E., 1989. Bootstrapping in ecosystems. BioScience 39, 230-237.

Pettit, N.E., Froend, R.H., Ladd, P.G., 1995. Grazing in remnant woodland vegetation: changes in species composition and life form groups. J. Vegetation Sci. 6, 121-130.

Plaisance, G., 1986. Évolution des paysages forestiers et arborés en Bourgogne et Franche-Comté de I'an mille à nos jours. Hommes Terres Nord [1986], 190-195.

Poiani, K.A., Richter, B.D., Anderson, M.G., Richter, H.E., 2000. Biodiversity conservation at multiple scales: functional sites, landscapes, and networks. BioScience 50, 133-146.

Ponge, J.F., 2003. Humus forms in terrestrial ecosystems: a framework to biodiversity. Soil Biol. Biochem. 35, 935-945.

Ponge, J.F., Chevalier, R., Loussot, P., 2002. Humus Index: an integrated tool for the assessment of forest floor and topsoil properties. Soil Sci. Soc. Am. J. 66, 1996-2001.

Ponge J.F., Gillet, S., Dubs, F., Fedoroff, E., Haese, L., Lavelle, P., 2003. Collembolan communities as bioindicators of land-use intensification. Soil Biol. Biochem. 35, 813-826.

Rescia, A.J., Schmitz, M.F., Martin de Agar, M.P., de Pablo, C.L., Pineda, F.D., 1995. Ascribing plant diversity to historical changes in landscape: a methodological approach. Landsc. Urb. Plan. 31, $181-194$.

Roem, W.J., Berendse, F., 2000. Soil acidity and nutrient supply ratio as possible factors determining changes in plant species diversity in grassland and heathland communities. Biol. Conserv. 92, $151-161$.

Shannon, C.E., 1948. A mathematical theory of communications. Bell Syst. Tech. J. 27, 379-423.

Sheil, D., Burslem, D.F.R.P., 2003. Disturbing hypotheses in tropical forests. TREE 18, 18-26.

Silverstone, J., Smith, B., 1988. Gaps in the canopy: the missing dimension in vegetation dynamics. Vegetatio 77, 57-60.

Thomas, S.C., Halpern, C.B., Falk, D.A., Liguori, D.A., Austin, K.A., 1999. Plant diversity in managed forests: understory responses to thinning and fertilization. Ecol. Monogr. 9, 864-879. 
1 Thompson, K., Green, A., Jewels, A.M., 1994. Seeds in soil and worm casts from a neutral grassland. Funct. Ecol. 8, 29-35.

3 Tilman, D., 1982. Resource Competition and Community Structure. Princeton University Press, 4 Princeton, New Jersey.

5 Tilman, D., 1999. Diversity and production in European grasslands. Science 286, 1099-1100.

6 Wardle, D.A., Nilsson, M.C., Gallet, C., Zackrisson, O., 1998. An ecosystem-level perspective of 7 allelopathy. Biol. Rev. 73, 305-319.

8 Watt, A.S., 1960. The effect of excluding rabbits from acidiphilous grassland in Breckland. J. Ecol. 48, 9 601-604.

10

Zobel, D.B., Antos, J.A., 1986. Survival of prolonged burial by subalpine forest understory plants. Am. Midl. Nat. 115, 282-287.

12 


\section{Figure captions}

2

3 Fig. 1. Distribution of mean ( \pm S.E.) plant species richness per $0.2 \mathrm{~m}^{2}$ plot (local plant biodiversity) and 4 land-use variety (Shannon Index) across six landscape units.

5

6 Fig. 2. Distribution of mean ( \pm S.E.) plant species richness per $0.2 \mathrm{~m}^{2}$ plot across six landscape units, 7 in woodland, grassland and arable crops.

8

9

Fig. 3. C.A. projection of additional and some main variables along axes 2 and 3 (bold $=$ higher; lower 10 values). 
Table 1. Land-use types and diversity indices in six landscape units (means \pm standard errors S.E.)

\begin{tabular}{|c|c|c|c|c|c|c|c|}
\hline Unit number & 1 & 2 & 3 & 4 & 5 & 6 & Plant species richness \\
\hline Deciduous forest & 16 & 1 & 8 & 0 & 3 & 0 & $3.57(0.45)$ \\
\hline Coniferous forest & 0 & 14 & 2 & 4 & 2 & 0 & $3.22(0.61)$ \\
\hline Clearcut & 0 & 1 & 0 & 1 & 0 & 0 & \\
\hline Hedgerow & 0 & 0 & 0 & 0 & 1 & 0 & \\
\hline Hay meadow & 0 & 0 & 4 & 4 & 4 & 0 & $13.33(1.36)$ \\
\hline Pasture & 0 & 0 & 1 & 3 & 6 & 2 & $13.08(0.82)$ \\
\hline Fallow & 0 & 0 & 0 & 1 & 0 & 5 & $10.33(1.82)$ \\
\hline Crop & 0 & 0 & 1 & 3 & 0 & 9 & $7.54(1.01)$ \\
\hline Land-use diversity (Shannon) & 0.00 & 0.10 & 0.43 & 0.73 & 0.54 & 0.41 & \\
\hline Plant species richness & $3.38(0.60)$ & $2.25(0.40)$ & $8.00(1.63)$ & $10.94(0.99)$ & $9.06(1.22)$ & $8.31(1.18)$ & \\
\hline
\end{tabular}




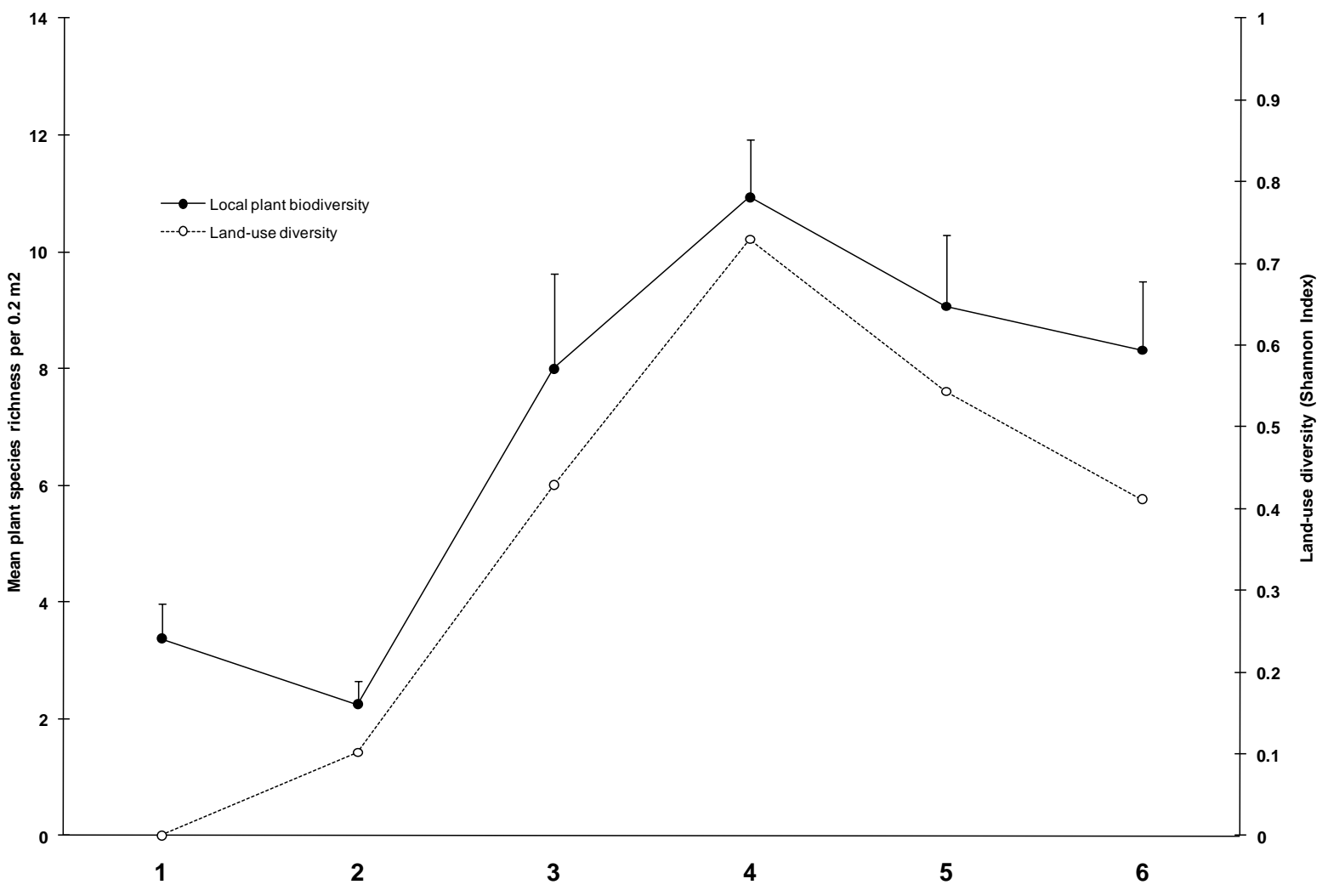

2 Fig. 1 


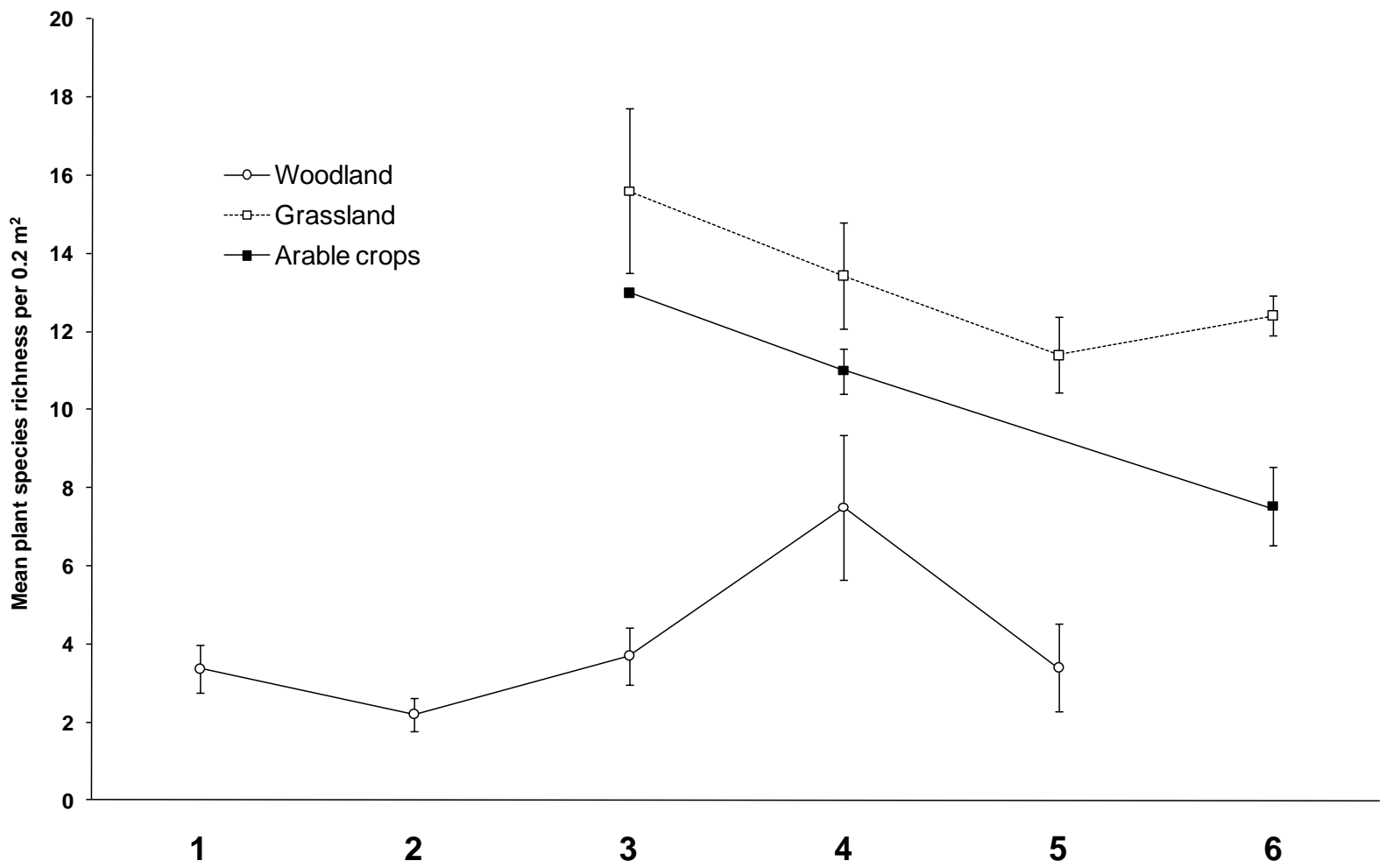

2 Fig. 2 
herb cover

species richness

tree cover

litter cover

Pasture

Hay meadow

5

all shrub cover

moss cover

total cover $44^{\text {Hedgerow }}$ lichen cover $\frac{n}{x}$

6

Fallow

Axis 2

tritee cover

species richness

herb cover

2 Fig. 3 